\title{
Hubungan antara Higiene Perorangan dengan Infeksi Cacing Usus (Soil Transmitted Helminths) pada Siswa SDN 25 dan 28 Kelurahan Purus, Kota Padang, Sumatera Barat Tahun 2013
}

\author{
Rizka Yunidha Anwar ${ }^{1}$, Nuzulia Irawati ${ }^{2}$, Machdawaty Masri ${ }^{3}$
}

\begin{abstract}
Abstrak
Infeksi cacing usus (helminthiasis) masih menjadi masalah kesehatan masyarakat di Indonesia yang prevalensinya lebih tinggi pada anak usia sekolah dasar (SD). Berdasarkan data Dinas Kesehatan Kota Padang, jumlah kasus infeksi cacing usus di Kota Padang tahun 2010 dilaporkan terbanyak kelima dari penyakit yang menyerang balita, yaitu sekitar $2.64 \%$. Tujuan penelitian ini adalah menentukan hubungan antara higiene perorangan siswa yaitu kebiasaan mencuci tangan, kebersihan kuku, penggunaan alas kaki dan kebiasaan mandi dengan infeksi cacing usus. Penelitian ini menggunakan desain observasional analitik dengan metode cross sectional pada 122 murid kelas 1 sampai kelas 6 SDN 25 dan 28 Purus Kota Padang pada bulan Desember 2013. Hubungan antara variabel dianalisis dengan uji Chi-Square. Hasil penelitian menunjukkan bahwa angka infeksi kecacingan di Purus $38.5 \%$, yang terinfeksi A.lumbricoides $33.6 \%$, T.trichiura $7.4 \%$ dan cacing tambang $0.8 \%$. Didapatkan nilai probabilitas untuk hubungan variabel kebiasaan mencuci tangan 0.235 , kebersihan kuku 0.564 , penggunaan alas kaki 0.133 , dan kebiasaan mandi dengan infeksi cacing usus 0.753. Kesimpulan studi ini ialah tidak terdapat hubungan yang bermakna antara kebiasaan mencuci tangan, kebersihan kuku, penggunaan alas kaki dan kebiasaan mandi dengan infeksi cacing usus pada murid SDN 25 dan 28 Purus, Kota Padang tahun 2013.
\end{abstract}

Kata kunci: higiene perorangan, infeksi cacing usus, siswa sekolah dasar, perilaku siswa

\section{Abstract}

Intestinal worm infection (helminthiasis) is a public health problems in Indonesia. Its prevalence is found higher on children. Based on data of Padang District Health Office, the prevalence of helminthiasis in Padang City at 2010 was reported the most 5th highest of disease that attacks toddler, it is about $2.64 \%$. The objective of this study was to determine the relation between the student's personal hygiene habits, such as washing hands, nail cleanliness, using footwear and bathing to the intestinal worm infection. This study used an observational analytic design method of cross -sectional study on 122 students in grade 1 to grade 6 in 25 and 28 primary school Purus, Padang in December 2013. Bivariat analysis was done using chi-square test with the confidence interval $95 \%$ at the significance level $5 \%$ $(\alpha=0.05)$. The result of this study showed that the rate of intestinal worm infection was $38.5 \%$. The infection rate of each worm types were roundworms $33.6 \%$, whipworms $7.4 \%$ and hookworms $0.8 \%$. The statistical test indicated the probability for the relation between the variable of hand washing, nail cleanliness, using footwear and bathing with helminthiasis were 0.235 ( $p>0.05), 0.564(p>0.05), 0.133(p>0.05)$ and $0.753(p>0.05)$ respectively. It can be concluded that there's no significant relation between personal hygiene and intestinal worm infection of the 25 and 28 primary school students in Purus, Padang.

Keywords: personal hygiene, intestinal worm infection, primary school students, student's behaviour

Affiliasi penulis: 1. Prodi Profesi Dokter FK UNAND (Fakultas Kedokteran Universitas Andalas Padang, 2. Bagian Parasitologi FK UNAND, 3. Bagian Farmakologi FK UNAND
Korespondensi: Rizka Yunidha Anwar, Emaill:

rizkayunidha.anwar@gmail.com, Telp: 082169161272 


\section{PENDAHULUAN}

Sebagai negara berkembang, Indonesia masih menghadapi masalah tingginya prevalensi penyakit infeksi terutama yang berkaitan dengan kondisi sanitasi lingkungan yang belum baik. Salah satu penyakit yang insidennya masih tinggi adalah infeksi kecacingan yang merupakan salah satu penyakit berbasis lingkungan. ${ }^{1}$ Hal tersebut dapat dimengerti mengingat bahwa Indonesia adalah negara agraris dengan tingkat sosial ekonomi, pengetahuan, keadaan sanitasi lingkungan dan higiene masyarakat yang masih rendah yang sangat mendukung untuk terjadinya infeksi dan penularan cacing. ${ }^{2}$

Salah satu penyakit kecacingan adalah penyakit infeksi cacing usus yang ditularkan melalui tanah (Soil Transmitted Helminths) yang masih dijumpai pada anak usia SD yang masih sering kontak dengan tanah. Ada empat jenis cacing yang terpenting yaitu cacing gelang (Ascaris lumbricoides), cacing cambuk (Trichuris trichiura) dan cacing tambang (Ancylostoma duodenale dan Necator americanus). ${ }^{1}$

Prevalensi penyakit kecacingan sangat tinggi terutama di daerah tropis dan subtropis, beriklim basah dimana higiene dan sanitasinya buruk. Jumlah kasus infeksi STHs (Soil Transmitted Helminths) terbanyak dilaporkan di kawasan Sub-Sahara Afrika, Benua Amerika, Cina dan Asia Timur. Infeksi terjadi oleh karena tertelan telur cacing dari tanah yang terkontaminasi atau dari penetrasi aktif melalui kulit oleh larva di tanah. ${ }^{3}$

Data hasil survei tahun 2002 di 10 provinsi di Indonesia dengan sasaran anak SD, prevalensi kecacingan di Indonesia antara 4,8\% - 83,0\%, prevalensi tertinggi di Provinsi Nusa Tenggara Barat diikuti Sumatera Barat dan yang terendah di Provinsi Jawa Timur. Hasil survei prevalensi kecacingan tahun 2003 dengan sasaran dan lokasi yang sama pada tahun 2002 menunjukkan hasil yang tidak jauh berbeda. Prevalensi kecacingan keseluruhan 33,1\% cacing gelang, $22,26 \%$ cacing cambuk dan $0,75 \%$ cacing tambang. ${ }^{4}$

Kurangnya pengetahuan anak tentang infeksi kecacingan merupakan faktor dasar seorang anak berperilaku. Intensitas dan prevalensi yang tinggi pada anak disebabkan oleh kebiasaan memasukkan jarijari tangan yang kotor ke dalam mulut. Pada infeksi cacing tambang, prevalensi yang tinggi didapatkan pada anak dengan umur lebih tua, hal ini kemungkinan disebabkan oleh mobilitas anak meningkat. ${ }^{5}$

Pengendalian penyakit cacingan merupakan tindakan yang bertujuan untuk menurunkan prevalensi dari intensitas penyakit cacing sehingga dapat menunjang peningkatan mutu sumber daya manusia, guna mewujudkan manusia Indonesia yang sehat. Dasar utama untuk pengendalian kecacingan adalah memutuskan mata rantai lingkungan hidup cacing dapat dilakukan pada tingkat cacing dalam tubuh manusia, lingkungan fisik, lingkungan sosial ekonomi dan budaya. ${ }^{6}$

Berdasarkan data terakhir di Kota Padang setelah gempa 30 September 2009 sekitar 9\% penduduk Kota Padang tidak mempunyai fasilitas pembuangan air limbah rumah tangga, terdapat $63,80 \%$ penduduk yang mempunyai septic tank sedangkan sisanya menggunakan kolam dan sungai sebagai sarana pembuangan air limbahnya. Kecamatan Padang Barat dengan kepadatan 8.858 jiwa/tahun. ${ }^{7}$ Kecamatan ini merupakan kawasan pusat kota dan kota tua. Kelurahan Purus merupakan salah satu kelurahan di Kecamatan Padang Barat yang memiliki kondisi sanitasi yang sangat buruk. ${ }^{8}$

Berdasarkan data pra penelitian yang dilakukan pada tanggal 20 - 23 Mei 2013 didapatkan 50\% dari 40 sampel yang diambil secara random sampling terinfeksi kecacingan. $\mathrm{Hal}$ tersebut dapat dipengaruhi oleh perilaku, lingkungan tempat tinggal dan manipulasi lingkungan, misalnya kepadatan penduduk, tidak tersedianya air bersih dan tempat pembuangan feses yang tidak memenuhi syarat kesehatan. ${ }^{5}$

Berdasarkan uraian di atas, perlu dilakukan penelitian tersebut karena masih didapatkan prevalensi kecacingan yang cukup tinggi dari hasil penelitian terdahulu, maka dilakukanlah penelitian serupa tentang "Hubungan antara higiene perorangan dan infeksi cacing usus pada siswa Sekolah Dasar Negeri 25 dan 28 di Kelurahan Purus, Kota Padang, Sumatera Barat." 


\section{METODE}

Penelitian yang dilakukan bersifat cross sectional study pada Januari 2013 sampai Januari 2014. Lokasi penelitian di SDN 25 dan SDN 28 Purus kota Padang sedangkan pemeriksaan telur cacing usus (Soil Transmitted Helminths) dilakukan di Laboratorium Parasitologi Fakultas Kedokteran Universitas Andalas. Subjek penelitian adalah murid SDN 25 dan 28 Purus, Padang yang berjumlah 122 orang yang memenuhi kriteria inklusi dan kriteria eksklusi. Cara pengambilan subjek yaitu dengan teknik total sampling. Instrumen penelitian yang digunakan adalah kuesioner dan pemeriksaan feses telur cacing usus. Data yang diperoleh diolah secara komputerisasi dan untuk analisis hasil penelitiannya digunakan uji statistik chi-square test dengan tingkat pemaknaan $p<0,05$.

\section{HASIL}

\section{Karakteristik Subjek Penelitian}

Berdasarkan hasil penelitian yang telah dilakukan pada siswa SD Negeri 25 dan 28 Purus Kota Padang tahun 2013 (Tabel 1) didapatkan karakteristik responden yang terdiri atas jenis kelamin, usia, tingkatan kelas, pendidikan orang tua dan pekerjaan orang tua pada Tabel 1 sebagai berikut :

1. Jenis Kelamin

Perempuan dan laki - laki memiliki angka yang seimbang, yaitu 61 orang $(50.0 \%)$ dari dua sekolah.

2. Usia

Usia terbanyak sebagai responden adalah usia 7 tahun sekitar 23 orang (18.9\%).

3. Tingkatan Kelas

Jumlah siswa terbanyak dari tingkatan kelas I SD, yaitu 25 orang (20.5\%), diikuti dengan kelas $\mathrm{V}$ sebanyak 23 orang (18.9\%) dan sedikit jumlah responden dari kelas II SD sebanyak 16 orang (13.1\%).

4. Pendidikan Orang Tua

Didapatkan pengelompokkan tingkat pendidikan orang tua dari pendidikan sekolah dasar sampai pendidikan lanjut atau sarjana memberikan gambaran kesenjangan, yaitu sebanyak 47 orang (36.5\%) pendidikan terakhir orang tua siswa hanya menempati pendidikan sekolah dasar, sementara yang mengenyam sarjana hanya sebesar 4 orang (3.3\%).

5. Pekerjaan Orang Tua

Pekerjaan orang tua siswa adalah sebagai buruh, yaitu sebesar 70 orang (57.4\%), peringkat berikutnya adalah sebagai pedagang sebanyak 25 orang $(20.5 \%)$, sedangkan jenis pekerjaan dengan prevalensi terkecil sebagai pegawai negeri sipil (PNS) yaitu 1 orang $(0.8 \%)$.

\section{Analisis Univariat}

1. Infeksi Cacing Usus

Didapatkan angka yang positif terinfeksi cacing usus sebanyak 47 orang dari 122 populasi (38.5\%). Sedangkan untuk distribusi infeksi cacing usus (Soil Transmitted Helminths) berdasarkan jenis cacing usus memiliki persentase paling banyak adalah positif infeksi A.lumbricoides sebanyak 41 orang (33.6\%), positif infeksi T.trichiura sebanyak 9 orang (7.4\%) dan yang terinfeksi cacing tambang hanya 1 orang $(0.8 \%)$. Dari total 51 orang yang terinfeksi, ada 4 orang yang terinfeksi oleh kedua jenis cacing usus yaitu A.lumbricoides dan T.trichiura.

2. Kebiasaan Mencuci Tangan

Persentase siswa yang mempunyai kebiasaan mencuci tangan kategori tidak baik sebanyak 21 orang (17.2\%). Angka tersebut lebih rendah dibandingkan dengan kebiasaan mencuci tangan kategori baik sebanyak 101 orang (82.8\%).

3. Kebersihan Kuku

Persentase siswa yang mempunyai kebersihan kuku yang tidak baik sebanyak 70 orang (57.4\%) lebih banyak dibandingkan siswa yang mempunyai kebersihan kuku yang baik sebanyak 52 orang $(42.6 \%)$.

4. Penggunaan Alas Kaki

Persentase siswa yang menggunakan alas kaki (sepatu atau sandal) saat keluar rumah atau saat sekolah lebih besar pada kategori sering yaitu sebanyak 109 orang (89.3\%). Sedangkan yang jarang menggunakan alas kaki hanya 13 orang $(10.7 \%)$ 
5. Kebiasaan Mandi

Diperoleh persentase yang lebih besar pada siswa yang mempunyai kebiasaan mandi yang baik yaitu sebanyak 114 orang (93.4\%). Angka lebih rendah didapatkan pada siswa yang mempunyai kebiasaan mandi yang tidak baik $(6,6 \%)$.

\section{Analisis Bivariat}

1. Hubungan antara Kebiasaan Mencuci Tangan dengan Infeksi Cacing Usus (Soil Transmitted Helminths)

Berdasarkan uji statistik tidak terdapat hubungan yang bermakna antara hubungan kebiasaan mencuci tangan dengan infeksi cacing usus (Soil Transmitted Helminths) pada siswa SDN 25 dan 28 Purus yang menjadi responden $P$ value $(0.235)>\alpha$ (0.05). (Tabel 2)

2. Hubungan antara Kebersihan Kuku dengan Infeksi Cacing Usus (Soil Transmitted Helminths)

Berdasarkan uji statistik tidak terdapat hubungan yang bermakna antara hubungan kebersihan kuku dengan infeksi cacing usus (Soil Transmitted Helminths) pada siswa SDN 25 dan 28 Purus yang menjadi responden $P$ value (0.564)> a (0.05) (Tabel 3)

3. Hubungan antara Penggunaan Alas Kaki dengan Infeksi Cacing Usus (Soil Transmitted Helminths)

Berdasarkan uji statistik tidak terdapat hubungan yang bermakna antara penggunaan alas kaki dengan infeksi cacing usus (Soil Transmitted Helminths) pada siswa SDN 25 dan 28 Purus yang menjadi responden $P$ value (0.133) $>\alpha(0.05)$. (Tabel 4)

4. Hubungan antara Kebiasaan Mandi dengan Infeksi Cacing Usus (Soil Transmitted Helminths)

Berdasarkan uji statistik tidak terdapat hubungan yang bermakna antara kebiasaan mandi dengan infeksi cacing usus (Soil Transmitted Helminths) pada siswa SDN 25 dan 28 Purus yang menjadi responden $P$ value $(0.753)>\alpha(0.05)$. (Tabel 5$)$
Tabel 1. Karakteristik responden pada siswa SDN 25 dan 28 Purus, Kota Padang tahun 2013

\begin{tabular}{|c|c|c|}
\hline & $f$ & $\%$ \\
\hline \multicolumn{3}{|l|}{ Jenis Kelamin } \\
\hline Laki-laki & 61 & 50.0 \\
\hline Perempuan & 61 & 50.0 \\
\hline \multicolumn{3}{|l|}{ Usia } \\
\hline 6 tahun & 5 & 4.1 \\
\hline 7 tahun & 23 & 18.9 \\
\hline 8 tahun & 19 & 15.6 \\
\hline 9 tahun & 21 & 17.2 \\
\hline 10 tahun & 21 & 17.2 \\
\hline 11 tahun & 20 & 16.4 \\
\hline 12 tahun & 9 & 7.4 \\
\hline 13 tahun & 3 & 2.5 \\
\hline 14 tahun & 1 & 0.8 \\
\hline \multicolumn{3}{|l|}{ Kelas } \\
\hline I & 25 & 20.5 \\
\hline II & 16 & 13.1 \\
\hline III & 20 & 16.4 \\
\hline IV & 21 & 17.2 \\
\hline V & 23 & 18.9 \\
\hline VI & 17 & 13.9 \\
\hline \multicolumn{3}{|l|}{ Pendidikan } \\
\hline \multicolumn{3}{|l|}{ Orang Tua } \\
\hline SD & 47 & 38.5 \\
\hline SMP & 44 & 36.1 \\
\hline SMA & 27 & 22.1 \\
\hline Sarjana & 4 & 3.3 \\
\hline \multicolumn{3}{|l|}{ Pekerjaan Orang } \\
\hline \multicolumn{3}{|l|}{ Tua } \\
\hline Buruh & 70 & 57.4 \\
\hline Nelayan & 18 & 14.8 \\
\hline Pedagang & 25 & 20.5 \\
\hline Pegawai & 8 & 6.6 \\
\hline \multicolumn{3}{|l|}{ swasta } \\
\hline PNS & 1 & 0.8 \\
\hline
\end{tabular}


Tabel 2. Hubungan antara kebiasaan mencuci tangan dengan infeksi cacing usus (Soil Transmitted Helminths) pada siswa SDN 25 dan 28 Purus, Kota Padang

\begin{tabular}{|c|c|c|c|c|c|c|c|}
\hline \multirow{3}{*}{$\begin{array}{c}\text { Kebiasaan } \\
\text { Mencuci } \\
\text { Tangan }\end{array}$} & \multicolumn{4}{|c|}{$\begin{array}{c}\text { Infeksi Cacing Usus } \\
\text { (Soil Transmitted } \\
\text { Helminths) }\end{array}$} & \multirow{2}{*}{\multicolumn{2}{|c|}{ Total }} & \multirow[t]{3}{*}{$\mathbf{p}$} \\
\hline & \multicolumn{2}{|c|}{ Negatif } & \multicolumn{2}{|c|}{ Positif } & & & \\
\hline & $f$ & $\%$ & $f$ & $\%$ & $\mathbf{n}$ & $\%$ & \\
\hline Tidak Baik & 10 & 8.2 & 11 & 9.0 & 21 & 17.2 & \multirow{3}{*}{0.235} \\
\hline Baik & 65 & 53.3 & 36 & 29.5 & 101 & 82.8 & \\
\hline$n$ & 75 & 61.5 & 47 & 38.5 & 122 & 100.0 & \\
\hline
\end{tabular}

Tabel 3. Hubungan antara kebersihan kuku dengan infeksi cacing usus (Soil Transmitted Helminths) pada siswa SDN 25 dan 28 Purus, Kota Padang

\begin{tabular}{|c|c|c|c|c|c|c|c|}
\hline \multirow{3}{*}{$\begin{array}{c}\text { Kebersihan } \\
\text { Kuku }\end{array}$} & \multicolumn{4}{|c|}{$\begin{array}{c}\text { Infeksi Cacing Usus } \\
\text { (Soil Transmitted } \\
\text { Helminths) }\end{array}$} & \multirow{2}{*}{\multicolumn{2}{|c|}{ Total }} & \multirow[t]{3}{*}{$\mathbf{p}$} \\
\hline & \multicolumn{2}{|c|}{ Negatif } & \multicolumn{2}{|c|}{ Positif } & & & \\
\hline & $f$ & $\%$ & $f$ & $\%$ & $\mathbf{n}$ & $\%$ & \\
\hline Tidak Baik & 41 & 33.6 & 29 & 23.8 & 70 & 57.4 & \multirow{3}{*}{0.564} \\
\hline Baik & 34 & 27.9 & 18 & 14.8 & 52 & 42.6 & \\
\hline $\mathrm{n}$ & 75 & 61.5 & 47 & 38.5 & 122 & 100.0 & \\
\hline
\end{tabular}

Tabel 4. Hubungan antara penggunaan alas kaki dengan infeksi cacing usus (Soil Transmitted Helminths) pada siswa SDN 25 dan 28 Purus, Kota Padang

\begin{tabular}{|c|c|c|c|c|c|c|c|}
\hline \multirow{3}{*}{$\begin{array}{c}\text { Penggunaan } \\
\text { Alas Kaki }\end{array}$} & \multicolumn{4}{|c|}{$\begin{array}{c}\text { Infeksi Cacing Usus } \\
\text { (Soil Transmitted } \\
\text { Helminths) }\end{array}$} & \multirow{2}{*}{\multicolumn{2}{|c|}{ Total }} & \multirow[t]{3}{*}{$\mathbf{p}$} \\
\hline & \multicolumn{2}{|c|}{ Negatif } & \multicolumn{2}{|c|}{ Positif } & & & \\
\hline & $f$ & $\%$ & $f$ & $\%$ & $n$ & $\%$ & \\
\hline Jarang & 5 & 4.1 & 8 & 6.6 & 13 & 10.7 & \multirow{3}{*}{0.133} \\
\hline Sering & 70 & 57.4 & 39 & 32.0 & 109 & 89.3 & \\
\hline $\mathrm{n}$ & 75 & 61.5 & 47 & 38.5 & 122 & 100.0 & \\
\hline
\end{tabular}

Tabel 5. Hubungan antara kebiasaan mandi dengan infeksi cacing usus (Soil Transmitted Helminths) pada siswa SDN 25 dan 28 Purus, Kota Padang

\begin{tabular}{|c|c|c|c|c|c|c|c|}
\hline \multirow{3}{*}{$\begin{array}{l}\text { Kebiasaan } \\
\text { Mandi }\end{array}$} & \multicolumn{4}{|c|}{$\begin{array}{c}\text { Infeksi Cacing Usus } \\
\text { (Soil Transmitted } \\
\text { Helminths) }\end{array}$} & \multirow{2}{*}{\multicolumn{2}{|c|}{ Total }} & \multirow[t]{3}{*}{$p$} \\
\hline & \multicolumn{2}{|c|}{ Negatif } & \multicolumn{2}{|c|}{ Positif } & & & \\
\hline & $f$ & $\%$ & $f$ & $\%$ & $n$ & $\%$ & \\
\hline Tidak Baik & 4 & 3.3 & 4 & 3.3 & 8 & 6.6 & \multirow{3}{*}{0.753} \\
\hline Baik & 71 & 58.2 & 43 & 35.2 & 114 & 93.4 & \\
\hline$n$ & 75 & 61.5 & 47 & 38.5 & 122 & 100.0 & \\
\hline
\end{tabular}

\section{PEMBAHASAN}

Hubungan antara Kebiasaan Mencuci Tangan dengan Infeksi Cacing Usus (Soil Transmitted Helminths) pada siswa SDN 25 dan 28 Purus, Kota Padang

Hasil uji statistik menunjukkan bahwa tidak terdapat hubungan yang bermakna antara kebiasaan mencuci tangan dengan infeksi cacing usus pada siswa SDN 25 dan 28 Purus. Penelitian ini mendukung hasil penelitian serupa yang dilakukan oleh Nusa et al. pada tahun 2013 di Kec. Damau Kab. Kep. Talaud. ${ }^{9}$ dan Endriani et al tahun 2010 di Kel. Karangroto Semarang. ${ }^{10}$ Berbeda dengan penelitian yang dilakukan oleh Jalaluddin pada tahun 2009 di Kota Lhokseumawe dan Rahmad pada tahun 2008 di Kec. Sibolga Kota yang menemukan adanya hubungan yang bermakna antara kebiasaan mencuci tangan dengan infeksi cacing usus pada siswa sekolah dasar. ${ }^{11,12}$

Tidak terdapatnya hubungan antara kedua variabel dalam penelitian ini mungkin disebabkan karena sebagian besar siswa sudah membiasakan mencuci tangan dengan sabun sebelum makan, setelah buang air besar, dan setelah bermain dengan tanah. Kebiasaan tersebut mungkin sudah didapatkan para siswa saat belajar dalam materi pelajaran Olahraga dan Kesehatan dan selalu diterapkan juga 
didalam lingkungan keluarga. Perbedaan dari beberapa penelitian terdahulu mungkin disebabkan dengan beberapa faktor lain yang mempengaruhi infeksi cacing usus, seperti faktor membeli makanan jajanan atau faktor sanitasi lingkungan.

\section{Hubungan antara Kebersihan Kuku dengan Infeksi Cacing Usus (Soil Transmitted Helminths) pada siswa SDN 25 dan 28 Purus, Kota Padang}

Hasil uji statistik menunjukkan bahwa tidak terdapat hubungan yang bermakna antara kebersihan kuku dengan infeksi cacing usus pada siswa SDN 25 dan 28 Purus. Penelitian ini mendukung penelitian yang dilakukan oleh Nusa et al pada tahun 2013 di Kec. Damau Kab. Kep.Talaud dan Endriani et al tahun 2010 di Kel. Karangroto Semarang bahwa tidak ada hubungan yang bermakna antara kebersihan kuku dengan infeksi cacing usus. ${ }^{9,10}$ Hasil yang berbeda didapatkan oleh Jalaluddin pada tahun 2009 di Kota Lhokseumawe dan Rahmad pada tahun 2008 di Kec. Sibolga Kota bahwa ada hubungan yang bermakna antara kebersihan kuku dengan infeksi cacing usus. $^{11,12}$

Tidak terdapatnya hubungan antara kedua variabel ini mungkin disebabkan karena aspek higiene perorangan lain seperti kebiasaan mencuci tangan yang baik juga dapat mengurangi kontaminasi cacing usus pada kuku yang bersih dan pendek. Pada anak yang masih duduk di kelas I - III SD pada saat makan masih disuapi oleh ibu atau pengasuhnya sehingga mengurangi kontaminasi dari tangan yang kotor ke mulutnya. Hasil wawancara dengan beberapa guru di kedua sekolah tersebut, didapatkan bahwa sekolah juga menerapkan program pemeriksaan kuku kepada para siswa setiap minggu.

Perbedaan hasil penelitian dari para peneliti sebelumnya disebabkan karena beberapa faktor higiene perorangan lain yang ditemukan. Pada penelitian Rahmad (2008) didapatkan prevalensi yang cukup tinggi pada anak yang sering menggigit kuku ketika sedang bermain dan memasukkan jari tangan kedalam mulut dan beberapa faktor sanitasi lingkungan yang buruk. ${ }^{12}$
Hubungan antara Penggunaan Alas Kaki dengan Infeksi Cacing Usus (Soil Transmitted Helminths) pada siswa SDN 25 dan 28 Purus, Kota Padang

Hasil uji statistik menunjukkan bahwa tidak ada hubungan yang bermakna antara penggunaan alas kaki dengan infeksi cacing usus pada siswa SDN 25 dan 28 Purus. Hal ini mungkin disebabkan karena jenis cacing usus yang sering ditemukan pada siswa di kedua SD tersebut adalah A.lumbricoides. Dari 122 sampel, hanya satu yang terinfeksi cacing tambang. Perilaku anak yang sudah memakai alas kaki ketika bermain di atas tanah berpasir sering ditemukan. Hal ini mungkin sudah diajarkan oleh kedua orang tua dan guru untuk melindungi kaki dari bahaya benda asing dan penyakit kecacingan yang dapat membahayakan keselamatan mereka.

Penelitian ini sejalan dengan yang dilakukan oleh Rahmad pada tahun 2008 di Kec. Sibolga Kota, Endriani et al. tahun 2010 di Kel. Karangroto Semarang dan Nusa et al tahun 2013 di Kab. Kep. Talaud bahwa tidak ada hubungan yang bermakna antara penggunaan alas kaki dengan infeksi cacing usus. ${ }^{9,10,12}$ Hasil yang berbeda pada penelitian yang dilakukan oleh Agustina tahun 2000 di Kec.Paseh Jawa Barat bahwa terdapat hubungan yang erat antara tanah yang tercemar telur A.lumbricoides dengan kejadian askariasis pada balita. ${ }^{13}$ Perbedaan tersebut mungkin disebabkan oleh prevalensi infeksi cacing tambang di setiap daerah yang berbeda dan sasaran pada usia anak prasekolah dan anak sekolah memiliki perbandingan yang berbeda untuk terinfeksi cacing tambang. Meskipun anak yang sudah memakai alas kaki lengkap tetap terinfeksi cacing usus, hal ini bisa terjadi karena dalam hal higiene perorangan dan sanitasi lingkungan tidak dilakukan dengan baik dan benar.

\section{Hubungan antara Kebiasaan Mandi dengan Infeksi Cacing Usus (Soil Transmitted Helminths) pada siswa SDN 25 dan 28 Purus, Kota Padang}

Hasil uji statistik menunjukkan bahwa tidak terdapat hubungan yang bermakna antara kebiasaan mandi dengan infeksi cacing usus pada siswa SDN 25 
dan 28 Purus. Hal ini disebabkan karena sebagian besar siswa telah mengenal dan menyadari akan pentingnya kebiasaan mandi yang baik seperti mandi dua kali sehari, mandi dengan menggunakan sabun dan menggosok badan, serta mandi saat badan berkeringat setelah melakukan aktivitas merupakan salah satu tindakan preventif dalam mencegah terjadinya infeksi cacing Oxyuris vermicularis (Enterobius vermicularis). Hasil serupa juga didapatkan dalam penelitian Nusa et al pada tahun 2013 di SD Kab. Kep.Talaud dan penelitian Ratag et al tahun 2011 di SD Negeri 119 Manado yang menyatakan tidak ada hubungan yang bermakna antara kebiasaan mandi dengan infeksi cacing usus. $^{9,14}$ Hasil yang berbeda dengan penelitian yang dilakukan oleh Lakodi tahun 2011 di Gorontalo bahwa ada hubungan antara kebiasaan mandi dengan infeksi cacing usus. $^{15}$

Perbedaan hasil dari beberapa penelitian terdahulu dapat disebabkan oleh perbedaan faktor higiene perorangan dan faktor sanitasi lingkungan.

\section{KESIMPULAN}

Tidak ada hubungan yang bermakna antara kebiasaan mencuci tangan dengan infeksi cacing usus (Soil Transmitted Helminths) pada siswa SD Negeri 25 dan 28 Purus Kota Padang.

Tidak ada hubungan yang bermakna antara penggunaan alas kaki dengan infeksi cacing usus (Soil Transmitted Helminths) pada siswa SD Negeri 25 dan 28 Purus Kota Padang.

Tidak ada hubungan yang bermakna antara kebersihan kuku dengan infeksi cacing usus (Soil Transmitted Helminths) pada siswa SD Negeri 25 dan 28 Purus Kota Padang.

Tidak ada hubungan yang bermakna antara kebiasaan mandi dengan infeksi cacing usus (Soil Transmitted Helminths) pada siswa SD Negeri 25 dan 28 Purus Kota Padang.

\section{SARAN}

Saran Untuk Dinas Kesehatan Kota Padang dan Puskesmas Purus adalah; dengan masih tingginya angkai infeksi cacing usus lebih dari $30.35 \%$ perlu dilakukan pemeriksaan dan pengobatan secara berkala tiap 6 bulan sekali pada siswa sekolah dasar.
Peningkatan perilaku hidup bersih dan sehat (PHBS) perlu dilakukan program penyuluhan dalam memberantas infeksi cacing usus (Soil Transmitted Helminths) yang diperuntukkan terutama melalui orang tua. Program penyuluhan kesehatan disamping meningkatkan pengetahuan orang tua, diharapkan pula akan meningkatkan kesadaran mereka untuk melakukan upaya pencegahan dan pengobatan secara mandiri.

\section{UCAPAN TERIMA KASIH}

Terima kasih kepada semua pihak atas bimbingan, bantuan dan motivasi dalam penelitian ini.

\section{DAFTAR PUSTAKA}

1. Departemen Kesehatan RI. Pedoman umum program nasional pemberantasan cacingan di era desentralisasi. Jakarta: Depkes RI; 2004.

2. Zit Z. Pengobatan infeksi cacing yang ditularkan melalui tanah dengan kombinasi mebendazol dan pirantel pada anak. Majalah Kedokteran Sriwijaya. 2000;32(1):46-50.

3. Webber R. Communicable disease epidemiology and control. Edisi ke-3. London: CAB Internationale; 2009

4. Ditjen PPM\&PL. Profile P2M \& PL. Jakarta: Dirjen PPM-PL; 2004.

5. Poespoprodjo JR, Sadjimin T. Hubungan antara tanda dan gejala penyakit cacing dengan kejadian kecacingan pada anak usia sekolah dasar di Kecamatan Ampama Kota Kabupaten Poso Sulawesi Tengah. Jurnal Epidemiologi Indonesia. 2000;4(1):9-15.

6. Sutanto I, Ismid IS, Sjarifuddin PK, Sungkar S. Buku ajar parasitologi kedokteran. Jakarta: FKUI; 2008.

7. Badan Pusat Statistik (BPS). Kependudukan dan perumahan penduduk Kota Padang setelah gempa 30 September 2009. Padang: BPS; 2009.

8. Nelza W, Soedjono ES. Strategi pengelolaan air limbah perkotaan Kota Padang, studi kasus Kecamatan Padang Barat (tesis). Surabaya: Program Pasca Sarjana Jurusan Teknik Lingkungan Institut Teknologi Sepuluh November 2011. 
9. Nusa LA, Jootje ML. Umboh, Victor D, Pijoh Hubungan antara higiene perorangan dengan infestasi cacing usus pada siswa SD yayasan pendidikan Imanuel Akas Kec. Damau Kab. Kepulauan Talaud (tesis). Manado: Program Studi Fakultas Kesehatan Masyarakat Universitas Sam Ratulangi; 2013.

10. Endriani, Mifbakhudin, Sayono. Beberapa faktor yang berhubungan dengan kejadian kecacingan pada anak usia 1-4 tahun. (tesis). Semarang. Program Studi Fakultas Kesehatan Masyarakat Universitas Muhammadiyah Semarang; 2010.

11. Jalaluddin. Pengaruh sanitasi lingkungan, personal hygiene dan karakteristik anak terhadap infeksi kecacingan pada murid sekolah dasar di Kecamatan Blang Mangat Kota Lhokseumawe (skripsi): 2009.

12. Rahmad RZ. Hubungan higiene perorangan siswa dengan infeksi kecacingan anak SD Negeri di
Kecamatan Sibolga Kota Sibolga (tesis). Medan: Program Pasca Sarjana Universitas Sumatera Utara; 2008.

13. Agustina. Telur Cacing Ascaris lumbricoides pada tinja dan kuku anak balita serta pada tanah di Kecamatan Paseh Kabupaten Bandung, Jawa Barat: 2000.

14. Ratag BT, Franckie RR, Maramis, Dareda K. Hubungan antara higiene perorangan dengan infestasi cacing usus pada siswa SD Negeri 119 Manado (tesis). Manado: Program Studi Fakultas Kesehatan Masyarakat Universitas Sam Ratulangi; 2011.

15. Lakodi Z. Perbedaan higiene perorangan dengan kejadian penyakit kecacingan di SDN 1 Libuo dan SDN 1 Maleo Kec. Paguat Kabupaten Pohuwaro (tesis). Gorontalo: Program Studi Kesehatan Masyarakat Fakultas IImu Kesehatan Masyarakat Universitas Negeri Gorontalo; 2011. 